\title{
Utilization of Durian Seed Flour as Filler Ingredient of Meatball
}

\author{
D. R. Malini ${ }^{a, *}$, I. I. Arief ${ }^{b}$, \& H. Nuraini ${ }^{b}$ \\ aPostgraduate Student of Department of Animal Production and Technology, Faculty of Animal Science, \\ Bogor Agricultural University \\ ${ }^{b}$ Department of Animal Production and Technology, Faculty of Animal Science, Bogor Agricultural University, \\ Jalan Agatis, Kampus IPB Dramaga Bogor 16680, Indonesia \\ (Received 03-05-2016; Reviewed 21-06-2016; Accepted 27-10-2016)
}

\begin{abstract}
Durian seed flour contains starch consisted of amylose and amylopectin like tapioca flour, so it can be utilized as a filler in meatball production. The purposes of this research were to evaluate the nutrient content and quality of durian seed flour, the best level of durian seed flour addition to the meatball production, and the quality of beef meatball during storage in room temperature and refrigerator. Completely randomized design (CRD) was used with 3 treatments and 3 replications. The treatments used different filler ingredients consisted of: 1) $100 \%$ tapioca, 2) $50 \%$ tapioca $+50 \%$ durian seed flour, and 3) $100 \%$ durian seed flour utilization. The results showed that durian seed flour could affect the protein levels and hardness of beef meatballs. In the organoleptic test, the addition of durian seed flour had no effect on the appearance of the color, flavor, aroma, and texture. The meatballs with $100 \%$ durian seed flour had the lowest hardness. The protein content of the meatballs with $100 \%$ durian seed flour was the highest. The used of $50 \%$ durian seed flour gave the best effect to beef meatball during storage. Meatball could be stored up to $8 \mathrm{~h}$ in room temperature while refrigerator could keep it longer up to $12 \mathrm{~d}$. It was concluded that the addition $50 \%$ durian seed flour may substitute tapioca flour as filler ingredient of beef meatball.
\end{abstract}

Key words: meatball, durian seed flour, filler ingredient

\begin{abstract}
ABSTRAK
Tepung biji durian memiliki kesamaan seperti tepung tapioka, yaitu memiliki kandungan pati yang terdiri atas amilosa dan amilopektin, sehingga dapat dimanfaatkan sebagai bahan pengisi makanan pada bakso. Penelitian ini bertujuan mengevaluasi kandungan nutrisi dan kualitas tepung biji durian, mengevaluasi tingkat penambahan tepung biji durian terbaik pada produksi bakso, dan mengevaluasi kualitas bakso selama penyimpanan suhu ruang dan dingin. Penelitian ini dirancang dengan menggunakan rancangan acak lengkap dengan 3 level perlakuan dan 3 ulangan. Perlakuan yang diberikan adalah perbedaan konsentrasi penambahan tepung biji durian sebagai bahan pengisi bakso daging sapi, antara lain: 1) $100 \%$ tepung tapioka, 2) $50 \%$ tepung tapioka $+50 \%$ tepung biji durian, dan 3) $100 \%$ tepung biji durian. Hasil penelitian menunjukkan bahwa tepung biji durian dapat mempengaruhi kadar protein dan tingkat kekerasan bakso. Pada uji organoleptik, penambahan tepung biji durian tidak berpengaruh terhadap parameter warna, rasa, aroma, dan tekstur. Bakso dengan penggunaan $100 \%$ tepung biji durian memiliki tingkat kekerasan paling rendah. Kadar protein bakso dengan penggunaan $100 \%$ tepung biji durian memiliki kadar protein tertinggi. Tepung biji durian dapat menjadi subtitusi tepung tapioka sebagai bahan pengisi bakso daging sapi dengan level pemberian $50 \%$. Bakso dengan pemberian tepung biji durian $50 \%$ mampu disimpan hingga jam ke-8 pada suhu ruang dan hari ke-12 pada suhu dingin. Dapat disimpulkan bahwa penambahan $50 \%$ tepung biji durian dapat digunakan sebagai bahan pengisi pengganti tapioka pada pembuatan bakso daging sapi.
\end{abstract}

Kata kunci: bakso, tepung biji durian, fisik, kimia

*Corresponding author:

E-mail: delviasaleh@yahoo.com 


\section{INTRODUCTION}

Durian (Durio zibethinus murr) is one of the most famous fruits in Indonesia. As king of fruits, durian belongs to Bombacaceae family and is also found in tropical region. The seed of ripe durian contains 51.1\% water, $46.2 \%$ carbohydrate, $2.5 \%$ protein, and $0.2 \%$ fat (Djaeni et al., 2010). A durian tree can produce $80-100$ fruits, but the old durian tree is able to produce 200 fruits. A lodicule in durian fruit may contain 2-6 pulps. Central of Statistics Buerau (2014) reported that durian production in Indonesia has increased every year. In 2013, durian production in Indonesia was around 1.818.949 tons.

The part of durian that is commonly consumed is the fruit flesh, which accounts for $20 \%-35 \%$ of fruit weight. Additionally, durian peel and seed account for $60 \%-75 \%$ and $5 \%-15 \%$ of fruit weight, which are not optimally used. Physically, durian seed has a sharp egg round and white yellowish or light brown color.

The high carbohydrate content of durian seed can be used as a substitution of carbohydrate source in the flour form. Both of durian seed starch and tapioca have amylose and amylopectin content. Tapioca contains about 20\%-27\% amylose (Moorthy, 2004), while durian seed contain approximately $22.35 \%$ amylose (Posoongnoen et al., 2015). Amylase can give firm characteristic and plays a role in gel forming, while amylopectin is responsible for the sticky and viscosity characteristic in food products. Based on these characteristics, both starch can be utilized as binding agents on foods such as meatball, sausage, and nugget.

Meatball constitutes a popular traditional meat product and is widely consumed, suggesting that it can provide high nutrient food (Widati et al., 2012). Meatball is commonly produced from meat and flour as main ingredients. Beef, chicken, and fish meat are usually used, while the flour is tapioca (Kusnadi et al., 2012). The survey was conducted by CDMI showed that the use of tapioca increased $10 \%$ per year in Indonesia. In 2013, the consumption of tapioca flour reached 3.33 million tons, while the production of tapioca flour was approximately 1.2 million tons. It will increase the number of tapioca import to fullfil the demand.

Durian seed has previously been reported to be used as material product of nugget (Rosyidi \& Widyastuti, 2014) and binding agent in tablet (Jufri et al., 2006). These efforts can support an innovation on creating nutritious foods. Based on those research, we tried to use durian seed flour as a substitution agent in meatball processing. It was hypothesized that durian seed flour could replace the use of tapioca flour as a binder to enhance the meatball quality. Therefore, the purposes of this research were to evaluate the nutrient content of durian seed flour, the quality of durian seed flour meatball, also the quality of meatball during storage at room temperature and in the refrigerator.

\section{MATERIALS AND METHODS}

\section{Materials and Instruments}

The materials used in this research were beef (topside commercial cuts, Brahman crossbred with
3 years old, from 3 male cattle as replications) from Elders slaughtering house in Bogor, tapioca, durian from Palembang city, sodium tripolyphosphate, and spices. Instruments used were meat grinder, aw meter (Novasina), RVA (rapid visco analyzer), texture analizer steven-LFRA, UV-VIS spectrophotometer (Agilent, Germany) and CR-600 colorimeter (Minolta Chroma Meter, Japan).

\section{Preparation of Durian Seeds Flour}

Durian seeds were selected based on the weight (35 g) and good condition, then properly washed. The washed seeds were peeled and soaked in hot water for $5 \mathrm{~min}$. The seeds were then soaked in 10\% calcium hydroxide ( $1 \mathrm{~L}$ distilled water $+10 \mathrm{~g}$ calcium) for $1 \mathrm{~h}$. The seeds were drained and sliced, and then dried for 3-4 d to obtain dried seeds. Ultimately, the dried seeds were milled and sieved.

\section{Meatball Processing}

Meatball processing procedures referred to Arief et al. (2012). Beef were cut into small form and grinded by using meat grinder, followed by the addition of salt, ice, and STTP (sodium tripolyphosphate) for $1 \mathrm{~min}$ (Figure 1). Furthermore, pepper, garlic, tapioca, and durian seed flour were added and ground for $1 \mathrm{~min}$. The meatball dough was roundly shaped and put into the $80{ }^{\circ} \mathrm{C}$ hot water for $10 \mathrm{~min}$ and then drained for $15 \mathrm{~min}$. The formulation of meatball was presented in Table 1.

\section{The Analysis Procedure of Meatball Characteristic}

The analysis procedure to evaluate characteristics of meatball conducted referred to many procedures. Colour analysis was conducted by the same procedures with Sharma (2003). Moisture, protein, fat, and ash contents of the sausages were analyzed using proximate analysis (AOAC, 2005), amilography followed Faridah et al. (2014), and rendemen was calculated according to Sani et al. (2014). Analysis of water absorption was carried out according to Rauf \& Sarbini (2015). Amylose, amilopectin, and starch content analysis according to Hartati \& Prana (2003). Texture was determined using a texture analyzer steven-LFRA as $\mathrm{kg} \mathrm{cm}^{-2}$ (Kusnadi et al., 2012). Analysis of total microbes and mold was conducted according to BAM (2001).

\section{Sensory Test}

Sensory test was carried out with hedonic test. The test used a scale of 1 to 5 with 40 untrained panelists and the parameters observed were colour, aroma, flavor, and texture (Arief et al., 2014).

\section{Meatball Quality During Storage}

The meatball made from the best treatment was stored at room temperature for $12 \mathrm{~h}$ and observed every $0,4,8$, and $12 \mathrm{~h}$. The meatball stored in the refrigerator $\left(4^{\circ} \mathrm{C}\right)$ for $12 \mathrm{~d}$ was observed on day $0,3,6,9$, and 12 . 


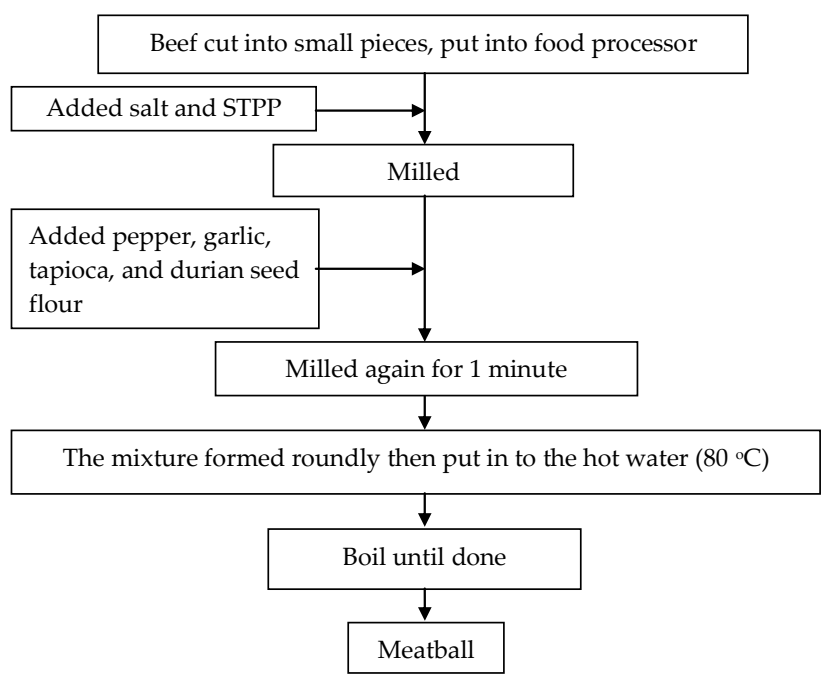

Figure 1. The scheme of meatball processing (Arief et al., 2012)

\section{Experimental Design}

This study was arranged using a completely randomized design (CRD) with 3 replications. The replications were 3 slaughtered cattle. The treatment was the addition of different concentrations of durian seed flour as a filler of meatballs. The concentration differences were as follows: 1) no substitution of durian seed flour, 2) substitution of $50 \%$ durian seed flour (tapioca flour : durian seed flour; $50: 50$ ), and 3) substitution of durian seed flour $100 \%$. Parameters measured were water absorption, $\mathrm{pH}, \mathrm{a}_{\mathrm{w}}$ texture, water content, ash content, protein, fat content, carbohydrate, and TPC.

\section{Statistical Analysis}

Data were analyzed using analysis of variance (ANOVA) to determine the effect of treatments and the differences among treatmens means were examined by Tukey test (Steel \& Torrie, 1993).

\section{RESULTS}

The results showed that durian seed flour had a brown color with value of $\mathrm{L}^{*} /$ brightness $=80.27, \mathrm{a}^{*}$ / redness $=1.49$, and $b^{*} /$ yellowness $=13.69$. Amilography properties of durian seed flour had gelatinization profile with peak viscosity of $1715 \mathrm{cp}$ and gelatinization temperature of $54.90^{\circ} \mathrm{C}$ was reached after 8 min of gelatinization process (Table 2). The use of the durian seed flour meatballs affected characteristics, such as hardness of meatballs and protein levels, whereas water absorption, $\mathrm{pH}, \mathrm{a}_{\mathrm{w}^{\prime}}$ elasticity, the cohesive ability, moisture content, ash content, fat content, carbohydrate, and total microbial were not affected (Table 3). The proximate content of durian seed flour included moisture, ash, protein, and fat content were suitable for SNI standard as food ingredient.

The organoleptic test showed no significant difference in the variables of color, flavor, aroma, and texture
Table 1 Formulation of meatball productions

\begin{tabular}{lccc}
\hline \multirow{2}{*}{ Ingredients } & \multicolumn{3}{c}{ Substitution of durian seed flour } \\
\cline { 2 - 4 } & $\begin{array}{c}\text { No } \\
\text { substitution }\end{array}$ & $\begin{array}{c}50 \% \\
\text { substitution }\end{array}$ & $\begin{array}{c}100 \% \\
\text { substitution }\end{array}$ \\
\hline Beef (g) & 400 & 400 & 400 \\
STPP (g) & 2 & 2 & 2 \\
Tapioca (g) & 60 & 30 & 0 \\
Durian seed & 0 & 30 & 60 \\
flour (g) & & & \\
Pepper (g) & 3 & 3 & 3 \\
Salt (g) & 12 & 12 & 12 \\
Garlic (g) & 4 & 4 & 4 \\
Ice (g) & 140 & 140 & 140 \\
\hline
\end{tabular}

Table 2 Durian seed flour characteristics

\begin{tabular}{|c|c|c|}
\hline Variables & $\begin{array}{c}\text { Durian } \\
\text { seed flour }\end{array}$ & Tapioca \\
\hline \multicolumn{3}{|l|}{ Colours } \\
\hline $\begin{array}{l}\text { CIE L* (dark-bright level with } \\
0-100)\end{array}$ & 80.27 & \\
\hline $\mathrm{CIE} \mathrm{a}^{*}(\operatorname{red}(+)$ and green $(-))$ & 1.49 & \\
\hline CIE b* (yellow (+) blue (-)) & 13.69 & \\
\hline \multicolumn{3}{|l|}{ Amylograph } \\
\hline Peak viscosity $(\mathrm{cp})$ & 1715 & $5387.94^{\mathrm{a}}$ \\
\hline Peak time (Menit) & 8 & $6.05^{\mathrm{a}}$ \\
\hline Gelatination temperature $\left({ }^{\circ} \mathrm{C}\right)$ & 54.90 & $69.56^{\mathrm{a}}$ \\
\hline Rendemen (\%) & 62 & $56.92-64.38^{\mathrm{b}}$ \\
\hline Amylose (\%/100g) & 22.35 & $20-27^{c}$ \\
\hline Amylopectin (\%/100g) & 66.33 & $82.13^{\mathrm{d}}$ \\
\hline Starch $(\% / 100 g)$ & 88.68 & $82.41^{\mathrm{e}}$ \\
\hline Water content $(\% b b)$ & 10.32 & $11.10^{\mathrm{e}}$ \\
\hline Ash content (\%bb) & 1.16 & $2.28^{\mathrm{e}}$ \\
\hline Protein $(\% b b)$ & 1.08 & $0.94^{\mathrm{e}}$ \\
\hline Fat content $(\% b b)$ & 5.40 & $0.34^{\mathrm{e}}$ \\
\hline Carbohydrate (\%bb) & 82.04 & $87.95^{\mathrm{e}}$ \\
\hline Fiber (\%bb) & 1.09 & $2.18^{\mathrm{e}}$ \\
\hline TPC (cfu/g) & $1.20 \times 10^{5}$ & - \\
\hline Molds (cfu/g) & $1.14 \times 10^{3}$ & - \\
\hline
\end{tabular}

Note: a Imanningsih (2012); ${ }^{b}$ Wijana et al. (2009); 'Moorthy (2004); ${ }^{\mathrm{d}} \mathrm{Helm}$ (2001); ' Charoenkul et al. (2011).

of the meatballs with the use of $100 \%$ durian seed flour (Table 4). The durian seed flour can substitute cassava flour as a filler material of beef meatballs with a $50 \%$ level. Panelists gave neutral to like perception on color, flavor, aroma, and texture of control meatball, 50\% durian seed flour meatball and $100 \%$ durian seed flour meatball.

Quality of meatballs could be maintained until $8 \mathrm{~h}$ during storage at room temperature and $12 \mathrm{~d}$ at refrigerated temperatures $\left(4^{\circ} \mathrm{C}\right)$ (Table 5). Water absorption, $\mathrm{pH}$ value, and aw of meatball were not affected by storage time during room temperature, but the total microbes 
Table 3. Meatball characteristics

\begin{tabular}{|c|c|c|c|}
\hline \multirow{2}{*}{ Variables } & \multicolumn{3}{|c|}{ Substitution of durian seed flour } \\
\hline & No substitution & $50 \%$ substitution & $100 \%$ substitution \\
\hline \multicolumn{4}{|l|}{ Physical quality } \\
\hline Water absorption (\%) & $5.18 \pm 0.64$ & $5.92 \pm 0.64$ & $5.92 \pm 0.64$ \\
\hline $\mathrm{pH}$ & $6.34 \pm 0.04$ & $6.42 \pm 0.02$ & $6.37 \pm 0.00$ \\
\hline$a_{w}$ & $0.888 \pm 0.04$ & $0.885 \pm 0.03$ & $0.887 \pm 0.01$ \\
\hline \multicolumn{4}{|l|}{ Texture } \\
\hline Hardness (gf) & $4,506.43 \pm 930.90^{a}$ & $2,908.83 \pm 778.36^{\mathrm{ab}}$ & $2,002.50 \pm 161.05^{\mathrm{b}}$ \\
\hline Elasticity (gf) & $81.79 \pm 0.10$ & $80.83 \pm 0.86$ & $80.51 \pm 0.31$ \\
\hline Cohesive ability (gf) & $0.51 \pm 0.04$ & $0.52 \pm 0.07$ & $0.51 \pm 0.05$ \\
\hline \multicolumn{4}{|l|}{ Chemical quality } \\
\hline Water content $(\% \mathrm{bb})$ & $74.61 \pm 0.47$ & $74.29 \pm 0.43$ & $73.70 \pm 0.43$ \\
\hline Ash content $(\% \mathrm{bb})$ & $2.28 \pm 0.06$ & $2.34 \pm 0.14$ & $2.35 \pm 0.24$ \\
\hline Protein $(\% b b)$ & $11.22 \pm 0.32^{\mathrm{b}}$ & $11.32 \pm 0.20^{\mathrm{b}}$ & $12.10 \pm 0.11^{\mathrm{a}}$ \\
\hline Fat content (\%bb) & $1.59 \pm 0.11$ & $2.09 \pm 0.37$ & $2.27 \pm 0.28$ \\
\hline Carbohydrate(\%bb) & $10.28 \pm 0.61$ & $9.94 \pm 0.30$ & $9.57 \pm 0.50$ \\
\hline \multicolumn{4}{|l|}{ Microbiology quality } \\
\hline TPC (log cfu/g) & $3.57 \pm 0.18$ & $3.62 \pm 0.41$ & $3.67 \pm 0.03$ \\
\hline
\end{tabular}

Note: Means in the same row with different superscripts differ significantly $(\mathrm{P}<0.05)$.

Table 4. Sensory characteristics of meatball

\begin{tabular}{cccc}
\hline \multirow{2}{*}{ Variables } & \multicolumn{3}{c}{ Substitution of durian seed flour } \\
\cline { 2 - 4 } & $\begin{array}{c}\text { No } \\
\text { substitution }\end{array}$ & $\begin{array}{c}50 \% \\
\text { substitution }\end{array}$ & $\begin{array}{c}100 \% \\
\text { substitution }\end{array}$ \\
\hline Color & $3.50 \pm 0.86$ & $3.60 \pm 0.67$ & $3.40 \pm 0.72$ \\
Flavor & $3.40 \pm 0.85$ & $3.46 \pm 0.81$ & $3.30 \pm 0.72$ \\
Aroma & $3.40 \pm 0.93$ & $3.43 \pm 0.62$ & $3.26 \pm 0.69$ \\
Texture & $3.50 \pm 0.90$ & $3.46 \pm 0.62$ & $3.43 \pm 0.67$ \\
Average & $3.45 \pm 0.50$ & $3.48 \pm 0.07$ & $3.34 \pm 0.80$ \\
\hline
\end{tabular}

Note: $1=$ Strongly dislike; $2=$ Dislike; $3=$ Neutral; $4=$ Like; $5=$ Like a lot.

was different. Before storage, total plate count of meatball was the lowest and increased during storage, but it was still met SNI standard (1994) up to $8 \mathrm{~h}$ at room temperature. Furthermore, $\mathrm{pH}$ value, $\mathrm{a}_{\mathrm{w}}$ and total microbes of meatball was significantly different at refrigerator temperature for $12 \mathrm{~d}$, but it was still met SNI standard.

\section{DISCUSSION}

\section{Durian Seed Flour}

The flour discoloration of durian seed from white to brown was caused by flour production (during seed mechanical grinding and drying). The mechanical grinding and drying process allows for the chemical reaction (browning non enzymatic/ Maillard reaction) between amino acids and reducing sugars that cause color changes to brown. Amid et al. (2013) reported that main amino acid components in the protein fraction of durian seed were leucine, lysine, aspartic acid, glycine, alanine, glutamic acid, valine, proline, and serine. Whereas the monosaccharides in the molecular structure of durian seed were glucose, arabinose and xylose. Mechanical grinding followed by drying of durian seed flour production revealed the covalent linkage between sugar and amino acids through Maillard reactions. Beside that, enzymatic browning might contribute to brown color of flour. When durian seed was cut, oxygen was introduced into the injured plant tissue., polyphenol oxidase (PPO) enzymes inside seed rapidly oxidize phenolic compounds naturally to o-quinones, and color changed to brown. Profile of gelatinization of durian seed flour was different with tapioca starch. Tapioca starch had a peak viscosity higher than the durian seed flour and it gelatinized faster (Table 2). Gelatinization characteristic and granule swelling of the starch were influenced by the amylopectin structure, starch composition, and starch granule size. This result was in accordance with Imanningsih (2012) that glutinous rice flour contained high amylopectin, $99.11 \%$ of the starch fraction, with gelatinization time of $5.87 \mathrm{~min}$.

Amylose content of durian seed flour was still within the range of amylose content of common starch. Moorthy (2004) found that tapioca contained 22\%-27\% of amylose. Amylose in the flour was responsible for firm characteristic and induced gel formation while high amylopectin content was associated with sticky properties (Hakim et al., 2013). The proximate content of durian seed flour had no sigificant difference from tapioca (Charoenkul et al., 2011).

In addition, microbiological evaluation was useful for determination of food quality. It was influenced by the food ingredient and production process (Hatta \& Murpiningrum, 2012). The physical characteristics of durian seed flour were presented in Table 2. 
Table 5. Meatball quality for storage

\begin{tabular}{|c|c|c|c|c|}
\hline Variables & $\begin{array}{c}\text { Water } \\
\text { absorption (\%) }\end{array}$ & $\mathrm{pH}$ & $a_{w}$ & $\begin{array}{c}\text { TPC } \\
(\log \mathrm{cfu} / \mathrm{g})\end{array}$ \\
\hline \multicolumn{5}{|c|}{ Room temperature $(\mathrm{h})$} \\
\hline 0 & $5.55 \pm 1.11$ & $6.07 \pm 0.07^{c}$ & $0.882 \pm 0.001$ & $3.75 \pm 0.16^{c}$ \\
\hline 4 & $5.18 \pm 0.64$ & $5.98 \pm 0.06^{c}$ & $0.883 \pm 0.001$ & $4.34 \pm 0.32^{b}$ \\
\hline 8 & $5.18 \pm 1.28$ & $6.57 \pm 0.10^{\mathrm{b}}$ & $0.884 \pm 0.005$ & $4.77 \pm 0.02^{\mathrm{b}}$ \\
\hline 12 & $4.81 \pm 0.64$ & $6.92 \pm 0.03^{a}$ & $0.885 \pm 0.001$ & $6.33 \pm 0.03^{a}$ \\
\hline \multicolumn{5}{|c|}{ Refrigerator temperature $(\mathrm{d})$} \\
\hline 0 & $5.55 \pm 1.11$ & $6.07 \pm 0.07^{\mathrm{r}}$ & $0.882 \pm 0.001 \mathrm{p}$ & $3.75 \pm 0.16^{\mathrm{r}}$ \\
\hline 3 & $7.40 \pm 1.60$ & $6.72 \pm 0.10^{q}$ & $0.867 \pm 0.01 \mathrm{q}$ & $3.92 \pm 0.05^{r}$ \\
\hline 6 & $7.03 \pm 0.64$ & $6.87 \pm 0.02^{p}$ & $0.863 \pm 0.01^{\mathrm{qr}}$ & $4.41 \pm 0.02^{q}$ \\
\hline 9 & $6.29 \pm 0.64$ & $6.84 \pm 0.01 p$ & $0.861 \pm 0.01^{\mathrm{s}}$ & $4.58 \pm 0.02^{q}$ \\
\hline 12 & $5.92 \pm 0.64$ & $6.81 \pm 0.03 p$ & $0.847 \pm 0.03^{\mathrm{t}}$ & $4.84 \pm 0.01^{p}$ \\
\hline
\end{tabular}

Note: Means in the same column with different superscript differ significantly $(\mathrm{P}<0.05)$.

\section{Meatball Characteristics}

The water absorption of the meatballs was affected by the amylose content. The durian seed flour has the same amylose content with tapioca, thus the water absorption of meatballs on this study was not significantly different. The $\mathrm{pH}$ was affected by raw ingredient such as meat (Montolalu et al., 2013). The use of 100\% tapioca in meatballs resulted in the higher hardness. Yu et al. (2009) stated that product firmness was also influenced by amylose content. It was due to strong hydrogen bond between amylose as well as between amylose and amylopectin. Furthermore, protein denaturation could cause textural changes, lost of water holding capacity, and shrinkage (Pramuditya \& Yuwono, 2014). Elasticity and cohesiveness were not significantly different.

The high water content in the meatballs caused lower capability of flour to absorb water (Pramuditya \& Yuwono, 2014; Putra et al., 2011). Ash content of the meatballs was also not significant $(\mathrm{P}>0.05)$ and was in agreement with SNI standard. SNI requirement (1995b) for maximum ash content is 3\%. The higher addition of flavor in the meatballs affected ash content. The highest protein content was found at meatballs made from 100\% durian seed flour, since protein in durian seed flour was higher than tapioca. The high protein content provided binding characteristics, thereby causing desirable stability of the product with compact texture (Mayashopha et al., 2015). The fat content of the meatballs made from $100 \%$ durian seed flour was higher than that of $100 \%$ tapioca, eventhough it was not significant. Fat content in durian seed flour $(5.40 \%)$ was higher than tapioca (0.34\%).

In general, all meatballs studied were in accordance with SNI requirements in both chemical and microbiological aspects. Maximum moisture, ash, fat content, and minimum protein content according to SNI were $70 \%, 3.0 \%, 2.0 \%$, and $9.0 \%$, respectively. Additionally, total maximum microbe was $1.0 \times 10^{5} \mathrm{cfu} / \mathrm{g}$.

\section{Meatball Sensory Characteristics}

Generally, all meatball treatments showed no significant effects on all sensory attributes. Mean of sensory scores was $\geq 3$, indicated that all characteristics of meatballs could be accepted by panelists with neutral to like perception. The value of color, flavor aroma, and texture were neutral to like for panelist. The addition of durian seed flour did not give any change in the acceptability of panelists. Panelist could accept $100 \%$ substitution of durian seed flour as well as utilization of tapioca starch as a filler ingredient of meatball. We believe that the results were due to similar characteristics of the meatballs, where water absorption, $\mathrm{pH}, \mathrm{a}_{\mathrm{w}^{\prime}}$ elasticity, the cohesive ability, moisture content, ash content, fat content, carbohydrate, and total microbial were not affected. By instrument analysis, the hardness of meatballs were different, however the panelists liked all meatballs. It was indicated that even though the hardness of meatballs with $100 \%$ substitution of durian seed flour was lowest, it could be accepted by the panelists.

\section{Meatball Quality During Storage}

Goulas \& Kontominas (2005) and Muratore et al. (2007) stated that increasing $\mathrm{pH}$ was caused by spoilage bacterial activity which could produce proteolytic enzyme. It could break down protein into ammonia, trimethylamine, and other volatile compounda. This study showed that increasing total microbe was observed in two treatments. The results exhibited that the meatballs could be acceptable for $8 \mathrm{~h}$ in room temperature and $12 \mathrm{~d}$ in refrigerator (temperature at $4^{\circ} \mathrm{C}$ ). Increasing microbial growth in refrigerator $\left(4^{\circ} \mathrm{C}\right)$ may due to the presence of psicotropic microbes.

The increasing $a_{w}$ in room temperature reduced protein capacity to bind water, thus water would be released (Afrianto et al., 2014; Kok \& Park, 2007). The changes in $\mathrm{a}_{\mathrm{w}}$ of the meatballs at refrigerator storage was caused by meatball desorption (dehydration) process. 
According to Wally et al. (2015), refrigeration condition was capable of retarding the bacterial growth.

\section{CONCLUSION}

The substitution of $50 \%$ tapioca with durian seed flour was considerable for meatball processing and indicated the best storage. Different levels of durian seed flour addition could affect the protein content $(100 \%$ durian seed flour) and meatball hardness value (100\% tapioca). The meatball storage could be acceptable for 8 $\mathrm{h}$ at room temperature and $12 \mathrm{~d}$ in refrigerator.

\section{REFERENCES}

Afrianto, E., E. Liviawaty, O. Suhara, \& H. Hamdani. 2014. Pengaruh suhu dan lama blasing terhadap penurunan kesegaran filet tagih selama penyimpanan pada suhu rendah. Jurnal Akuatika V:45-54.

Amid B, H., H. Mirhosseni, H. Poorazarang, \& S. A. Mortazavi. 2013. Implications of partial conjugation of whey protein isolate to durian seed gum through maillard reactions: foaming properties, water holding capacity and interfacial activity. Molecules 18:15110-15125. http://dx.doi. org/10.3390/molecules 181215110

[AOAC] Association of Analitycal Chemist. 2005. Official methods of analysis of the association official analytical chemistry. Virginia (USA): Arlington.

Arief, I. I., B. S. L. Jenie, T. Suryati, G. Ayuningtyas, \& A. Fuziawan. 2012. Antimicrobial activity of bacteriocin from indigenous Lactobacillus plantarum 2C12 and its application on beef meatball as biopreservative. Journal of the Indonesian Tropical Animal Agriculture 37: 90-96. http:// dx.doi.org/10.14710/jitaa.37.2.90-96

Arief, I. I., T. Suryati, D. N. Afiyah, \& D. P. Wardhani. 2014. Physicochemical and organoleptic of beef sausages with teak leaf extract (Tectona grandis) addition as preservative and natural dye. International Food Research Journal 21:2033-2042.

[BAM] Bacterial Analitical Manual. 2001. Aerobic Plate Count. U.S. Food and Drugs Administration.

[BSN] Badan Standarisasi Nasional. 1994a. Tepung Tapioka. SNI-01-3451-1994. Jakarta (ID):BSN.

[BSN] Badan Standarisasi Nasional. 1994b. Bakso daging. SNI01-3947-1995. Jakarta (ID):BSN

Charoenkul, N., D. Uttapap, W. Pathipanawat, \& Y. Takeda. 2011. Physicochemical characteristics of starches and flours from cassava varieties having different cooked root textures. LWT-Food Science and Technology 44: 1774-1781. http://dx.doi.org/10.1016/j.lwt.2011.03.009

Central of Bureau Statistics (BPS). 2014. Fruits Production by Province (Ton). Jakarta.

Djaeni, M. \& A. Prasetyaningrum. 2010. Kelayakan biji durian sebagai bahan pangan alternatif: Aspek nutrisi biji durian. Riptek IV: 37-45.

Faridah, D. N, D. Fardiaz, N. Andarwulan, \& T. C. Sunarti. 2014. Karakteristik sifat fisiko kimia pati garut (Maranta arundinaceae). Agritech 34:14-21.

Goulas, A. E. \& M. G. Kontominas. 2005. Effect of salting and smoking-method on the keeping quality of chub mackerel (Scomber japonicus): biochemical and sensory attributes. Food Chemistry 93: 511-520. http://dx.doi.org/10.1016/j. foodchem.2004.09.040

Hakim, U. N, D. Rosyidi, \& A. S. Widati. 2013. The effect of aroowroot flour (Maranta arrundinaceae) on physical and sensoric quality of rabbit nugget. Jurnal Ilmu dan Teknologi Hasil Ternak 8: 9-22
Hartati, N. S. \& T. K. Prana. 2003. Analisis kadar pati dan serat kasar tepung beberapa kultivar talas (Colocasia esculenta L. Schott). Jurnal Natur Indonesia 6: 29-33 .

Hatta, M. \& E. Murpiningrum. 2012. Beef meatballs quality prepared with salt and phosphate addition at various levels and time. Jurnal Ilmu dan Teknologi Peternakan 2: 30-38.

Imanningsih, N. 2012. Profil gelatinisasi beberapa formulasi tepung-tepungan untuk pendugaan sifat pemasakan (Gelatinisation profile of several flour formulations for estimating cooking behaviour). Penelitian Gizi dan Makanan (The Journal of Nutrition and Food Research) 35: 13-22.

Jufri, M., R. Dewi, \& A. R. Firli. 2006. Studi kemampuan pati biji durian sebagai bahan pengikat dalam tablet ketoprofen secara granulasi basah. Majalah Ilmu Kefarmasian 3: 78-86.

Kok, T. N. \& J. W. Park. 2007. Extending the shelf life of set fish ball. Journal of Food Quality 30:1-27. http://dx.doi. org/10.1111/j.1745-4557.2007.00103.x

Kusnadi, D. C., V. P. Bintoro, \& A. N. Al-Baarri. 2012. Daya ikat air, tingkat kekenyalan dan kadar protein pada bakso kombinasi daging sapi dan daging kelinci. Jurnal Aplikasi Teknologi Pangan 1:28-31.

Mayashopha, A. Y., F. Herfianita, \& A. Sutrisno. 2015. Application of transglutaminase enzyme on food product: A revew. Jurnal Pangan dan Agroindustri 3: 1145-1151.

Montolalu, S., N. Lontaan, S. Sakul, \& A. D. P. Mirah. 2013. Sifat fisiko kimia dan mutu organoleptik bakso broiler dengan menggunakan tepung ubi jalar (Ipomoea batatas $L$ ). Jurnal Zootek 32:1-13.

Moorthy, S. N. 2004. Tropical Sources of Starch. In: A. C. Eliassion (Ed.) Starch in Food: Structure, Function and Applications. Woodhead Publishing Limited/CRC Press LLC, Cambridge/New York. pp. 321-359. http://dx.doi. org/10.1533/9781855739093.2.321

Muratore, G., A. Mazzaglia, C. M. Lanza, \& F. Licciardello. 2007. Process variables on the quality of swordfish filled flavored with smoke condensate. Journal of Food Processing and Preservation 31:167-177. http://dx.doi. org/10.1111/j.1745-4549.2007.00120.x

Posoongnoen, S., R. Ubonbal, S. Thammasirirak , J. Daduang, H. Minami, K. Yamamoto, \& S. Daduang. 2015. $\alpha$-Amylase from Mon Thong durian (Durio zibethinus Murr. cv. Mon Thong) nucleotide sequence analysis, cloning and expression. Plant Biotechnology. 32: 1-10. http:// dx.doi.org/10.5511/plantbiotechnology.14.1122a

Pramuditya, G. \& S. S. Yuwono. 2014. Penentuan atribut mutu tekstur bakso sebagai syarat tambahan dalam SNI dan pengaruh lama pemanasan terhadap bakso. Jurnal Pangan dan Agroindustri 2:200-209.

Putra, A. A., N. Huda, \& R. Ahmad. 2011. Changes during the processing of duck meatballs using different fillers after the heating and preheating process. International Journal of Poultry Science 10:62-70. http://dx.doi.org/10.3923/ ijps.2011.62.70

Rauf, R. \& D. Sarbini. 2015. Water absorption as reference to teh volume of water in dough making from wheat flour and cassava for mixtures. Agritech 35:324-330

Rosyidi, D. \& E. S. Widyastuti. 2014. Pengaruh penambahan pati biji durian terhadap kualitas kimia dan organoleptik nugget ayam. Jurnal Ilmu-Ilmu Peternakan 23: 17-26.

Sani, R. N., F. C. Nisa, R. D. Andriani, \& J. M. Maligan. 2014. Yield analisis and phytochemical screening ethanol extract of marine microalgae Tetraselmis chuii. Jurnal Pangan dan Agroindustri 2:121-126

Sharma, G. 2003. Digital Color Imaging Handbook. Ed. CRC Press. Catalog no. 0900, c. 784 pp.

Steel, R. G. \& J. H. Torrie. 1993. Prinsip dan Prosedur Statistika. Gramedia Pustaka Utama, Jakarta. p 772.

Wally, E., F. Mentang, \& R. I. Montolalu. 2015. Kajian mutu 
kimiawi ikan cakalang (Katsuwonus pelamis L.) asap (FUFU) selama penyimpanan suhu ruang dan suhu dingin. Jurnal Media Teknologi Hasil Perikanan 3:7-12.

Widati, A. S., E. S. Widyastuti, Rulita, \& M. S. Zenny. 2012. The effect of addition tapioca starch on quality of chicken meatball chips with vacuum frying method. Jurnal Ilmuilmu Peternakan 21: 11-27.

Wijana S, I. Nurika, \& E. Habibah. 2009. Quality feasibility analysis on the tapioca flour processed from dried cassava (The effect of dried cassava origin and calcium hypochlorite concentration used). Jurnal Teknologi Pertanian 10:97-105

Yu, S., M. Ying, \& S. D. Wen. 2009. Impact of amylase content on start retrogradation and texture of cooked milled rice during storage. Journal of Cereal Science 50:139-144. http:// dx.doi.org/10.1016/j.jcs.2009.04.003 